\title{
Differential Expression of Genes Associated With Degradation Enhancement of Imazethapyr in Barnyardgrass (Echinochloa crus-galli)
}

\author{
Giliardi Dalazen ${ }^{1}$, Catarine Markus ${ }^{1} \&$ Aldo Merotto Jr. ${ }^{1}$ \\ ${ }^{1}$ Department of Plant Science, Federal University of Rio Grande do Sul, Porto Alegre, RS, Brazil \\ Correspondence: Giliardi Dalazen, Department of Plant Science, Federal University of Rio Grande do Sul, Porto \\ Alegre, RS, Brazil. Tel: 55-51-3308-6013. E-mail: giliardidalazen@gmail.com
}

Received: May 27, 2018

Accepted: July 3, $2018 \quad$ Online Published: August 15, 2018

doi:10.5539/jas.v10n9p389

URL: https://doi.org/10.5539/jas.v10n9p389

The research is financed by the Brazilian National Council for Scientific and Technological Development $(\mathrm{CNPq})$.

\begin{abstract}
The understanding of mechanism of herbicide resistance in weeds is essential for adequate or innovative weed management practices. The aim of this study was to identify and analyze the expression of genes related to degradation enhancement of imazethapyr in barnyardgrass (Echinochloa crus-galli L. Beauv.). One susceptible (SUSSP01) and two populations previouslly identified as resistant to imazethapyr (ARRGR01 and PALMS01) were used. Gene expression of $C Y P$ and $G S T$, the translation initiating factor $e I F 4 B$, and $A L S$ genes were evaluated after imazethapyr spraying. A reference gene stability analysis was carried out, wherein the genes $18 S$ and actin showed to be more stable in response to the population and herbicide treatment. The gene expression analysis was performed by qRT-PCR. There was no difference in the relative expression of the $A L S$ gene. The CYP81A6 and GSTF1 genes showed higher relative expression in the resistant populations. The CYP81A6 gene had expression 9.61 and 8.44 higher in the resistant populations ARRGR01 and PALMS01, respectively, in comparison with the untreated susceptible population. The expression of this gene was induced by spraying the herbicide imazethapyr. The GSTF1 gene showed higher relative expression in PALMS01 population, reaching 12.30 times higher in plants treated with imazethapyr in relation to untreated susceptible population. The expression of $e I F 4 B$ gene in the resistant populations treated with imazethapyr was about six times higher than observed in susceptible population. The high relative expression of CYP81A6 and GSTF1 genes indicate the importance of degradation enhancement for the resistance of barnyargrass to imazethapyr.
\end{abstract}

Keywords: imidazolinones, ALS, CYP, GST, herbicide resistance

\section{Introduction}

The resistance of weeds to herbicides is related to the occurrence of two primary mechanisms of resistance grouped as target site resistance (TSR) and non target site resistance (NTSR) (Powles \& Yu, 2010). The TSR is associated mainly with mutation in the target enzyme encoding gene and increase activity of the target enzyme. NTSR mechanisms encompass the resistance caused by lower uptake and variation of herbicide translocation, rapid necrosis caused by reactive oxygen species, herbicide sequestration in the vacuole, and degradation enhancement of the herbicide (Sammons \& Gaines, 2014; Yu \& Powles, 2014; Nandula et al., 2015).

The degradation enhancement of herbicides by detoxifying enzymes has been associated with the resistance in several weed species, especially the Lolium rigidum Gaud. (Yu, Abdallah, Han, Owen, \& Powles, 2009; Busi, Vila-Aiub, \& Powles, 2011), Alopecurus myosuroides Huds. (Délye, Gardin, Boucansaud, Chauvel, \& Petit, 2011) and Echinochloa phyllopogon Stapf. (Yasour et al., 2009; Iwakami et al., 2014a). The main enzymes related with herbicide detoxification include cytochrome P450 monooxygenases (known as CYP or P450) and glutathione S-transferases (GST) (Powles \& Yu, 2010). The enzymes P450 and GST are fundamental in phases I and II of herbicide metabolism, respectively (Yuan et al., 2007). The resistance due to increased metabolization is particularly alerting, since the same enzyme can detoxify more than one herbicide, leading to cross- and multiple resistance (Beckie \& Tardif, 2012). 
Barnyardgrass (Echinochloa crus-galli L. Beauv.) is a major weed of irrigated rice fields around the world (Chauhan \& Johnson, 2011). This weed can cause 21-79\% yield rice losses, depending on weed density, rice cultivar and irrigation management (Bajwa et al., 2015), and demands intensive use of different methods of control Herbicides are the most used method for controlling this weed, and acetolactate synthase (ALS) inhibitors, such as imidazolinones, are widely used. The availability of imidazolinone-resistant rice cultivars (Clearfield $\mathbb{R}$ rice) have allowed the repetitive use of these herbicides, selecting resistant barnyardgrass populations. In southern Brazil, the mechanism of resistance of these populations involves both types: mutations in the $A L S$ enconding gene and increased metabolism by detoxifying enzymes (Matzenbacher, Bortoly, Kalsing, \& Merotto Jr., 2015). In this study the effect of degradation enhancement as the mechanim of resistance was inferred through P450 inhibitors. However, the genetic regulation of this process is unknown in these populations.

The involvement of CYP and GST genes has been associated with herbicide resistance in weeds and selectivity in crops. The CYP81A is one of the most important gene subfamilies associated with the metabolization of herbicides in plants. The CYP81A6 gene has already been related to the metabolism of bensulfuron-methyl and sulfonylureas in rice (Pan et al., 2006; Liu et al., 2012). Similarly, a CYP81 gene is involved in the resistance of $A$. japonicus to the herbicide fenoxaprop- $P$-ehtyl (Chen, Xu, Zhang, Bai, \& Dong, 2018). In E. phyllopogon, the higher expressions of the CYP81A12 and CYP81A21 genes are associated with resistance to the ALS-inhibiting herbicides penoxsulam and bensulfuron-methyl (Iwakami et al., 2014a). In this species, previous spraying of bispyribac-sodium, another ALS inhibitor, induced the expression of CYP71AK2 and CYP72A254 genes in plants resistant to these herbicides (Iwakami et al., 2014b). In rice and Arabidopsis thaliana, the CYP72A31 gene confers tolerance to bispyribac-sodium (Saika et al., 2014). GST genes encode enzymes that catalyze conjugation reactions of herbicides with more soluble molecules, decreasing the phytotoxicity of the compounds (Yuan et al., 2007),. These enzymes also have other functions in herbicide detoxification, such as peroxidase activity and stress signaling (Dixon et al., 2002; Powles \& Yu, 2010; Cummins et al., 2013). The GSTF1 gene conferred greater tolerance to the herbicides chlorotoluron and fenoxaprop- $P$-ethyl in $A$. myosuroides and $L$. rigidum, causing multiple resistance (Cummins et al., 2013). In rice, overexpression of the GSTL1 or GSTL2 genes led to greater tolerance to chlorsulfuron and glyphosate (Hu, Qv, Xiao, \& Huang, 2009; Hu, 2014). Likewise, the greater expression of the GST1 gene has been related with resistance of E. crus-galli plants to quinclorac (Li et al., 2013).

The qRT-PCR (quantitative reverse transcription-polymerase chain reaction) is useful to access the gene expression, which is associated with enzyme activity. In this procedure it is necessary to analyze the stability of reference genes used for calculating the relative expression of the target gene. A number of studies demonstrate that the expression of reference genes widely used in this type of study can vary considerably with experimental conditions, tissues and species (Thellin et al., 1999; Stürzenbaum \& Kille, 2001). The analysis of the stability in the expression of reference genes in weeds responding to herbicide stress has already been performed in $A$. myosuroides for the acetyl CoA carboxylase (ACCase) inhibitors herbicides (Petit, Permin, Heydel, \& Délye, 2012), and in L. rigidum for ALS inhibitors herbicides (Duhoux \& Délye, 2013). In these studies, the most stable reference gene for A. myosuroides and L. rigidum were genes coding for tubulin and CAP proteins, respectively. The stability of reference genes for barnyardgrass under stress by herbicides has not been investigated yet.

The objectives of this study were to evaluate the stability of reference genes and the expression of CYP and GST genes in imidazolinone-susceptible and -resistant barnyardgrass populations exposed to imazethapyr.

\section{Method}

\subsection{Plant Material}

The source of susceptible population was at Engenheiro Coelho, SP (SUSSP01) and the resistant populations were at Arroio Grande-RS (ARRGR01) and Palmares do Sul-RS (PALMS01). Barnyardgrass resistant populations were collected from paddy fields of South Brazil, where escapees of control with imidazolinone

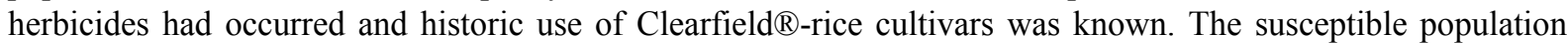
SUSSP01 was originally from an area where no herbicides had been applied before and efficient control had been obtained during previous pot-studies using imazethapyr. The PALMS01 population is resistant to imidazolinones due to the mutation Ser653Asn in $A L S$, but enhanced metabolism was also identified trough P450 inhibitors (Dalazen, Pisoni, Rafaeli, \& Merotto Jr., in press). Meanwhile, in the population ARRGR01 there was absence of $A L S$-gene mutation associated with herbicide resistance (Matzenbacher et al., 2015).

The seed dormancy overcoming was performed by immersing the seeds in $\mathrm{KNO}_{3}$ solution $(0.2 \%)$ at a temperature of $25{ }^{\circ} \mathrm{C}$ until germination (radicle emission), which occurred approximately four days after immersion. The seeds were then rinsed in distilled water and placed in Petri dishes incubated at $25{ }^{\circ} \mathrm{C}$ until the 
emergence of the first leaf. Then, seedlings were transplanted into $200 \mathrm{ml}$ pots filled with a mixture of ultisol and organic compound at a ratio of 10:1, and the mineral fertilizer (05-20-20 NPK complex) at $2.5 \mathrm{~g} \mathrm{~kg}^{-1}$. Plants were maintained in greenhouse with temperatures ranging from 25 to $27{ }^{\circ} \mathrm{C}$, relative humidity of about $70 \%$ and photoperiod of 14/10 hours (day/night).

The herbicide imazethapyr was sprayed at the label dose of $106 \mathrm{~g} \mathrm{ha}^{-1}$ plus adjuvant (Dash $0.5 \% \mathrm{v} / \mathrm{v}$ ). The spray treatments were applied in plants with three to four leaves stage using an automated spray chamber with nozzle TJ8002E, spray pressure of 2.89 bar and speed of $1.16 \mathrm{~m} \mathrm{~s}^{-1}$, resulting in a spray volume of $200 \mathrm{~L} \mathrm{ha}^{-1}$.

Leaves of barnyardgrass plants treated and untreated with imazethapyr were analyzed. The samples were collected before (T0, unreated control) and 24 hours after herbicide spraying (T24). Three biological replicates were used. The samples were collected in a $1.5 \mathrm{~mL}$ microtube and immediately conditioned in liquid nitrogen $\left(\mathrm{LN}_{2}\right)$. The samples were stored in an ultrafreezer $\left(-85^{\circ} \mathrm{C}\right)$ until the RNA extractions.

\subsection{RNA Extraction and cDNA Synthesis}

RNA extraction was performed using the Trizol ${ }^{\circledR}$ method (Invitrogen). The RNA was quantified in a spectrophotometer (Genesys $2^{\mathrm{TM}}$, Thermo Spectronic) at a wavelength of $260 \mathrm{~nm}$ and diluted in RNAse free water at $1 \mu \mathrm{g} \mu \mathrm{L}^{-1}$. Each sample was purified with DNAse ${ }^{\circledR}$ I (Invitrogen) in an amount of $1 \mu \mathrm{g}$ of total RNA, as per the manufacturer's recommendation. The next step consisted of obtaining the cDNA strand from RNA through SuperScrip ${ }^{\circledR}$ III reverse transcriptase (Invitrogen) in the amount of $1 \mu \mathrm{g}$ of RNA using polidT primers.

\subsection{Candidate Genes and Primer Design}

The reference genes (Table B1) evaluated for stability analysis were selected from the study of Duhoux and Délye (2013), including actin, CAP (catabolite activator protein), EFl (elongation factor 1), rubisco, ubiquitin, $18 S$ (18S ribosomal RNA) and $28 S$ (28S ribosomal RNA). The candidate genes CYP and GST were chosen based on a large literature review (Table B2). The analyzed genes were CYP81A6, CYP81A12, CYP81A21, CYP71C30, CYP71AK2, CYP72A254, CYP72A3, GSTF1, and GSTL1. In addition to these genes, the expression of $A L S$ and eIF4B (translation initiator factor) was considered. The eIF4B gene is present in the genus Echinochloa (Iwakami et al., 2014b) and its involvement in the detoxification of xenobiotics in other eukaryotic organisms has been reported (Kim et al., 2011).

The primers sequences were designed by the program Primer3Plus (http://www.bioinformatics.nl/cgi-bin/ primer3plus/primer3plus.cgi) from the most conserved region of each sequence obtained in the Genbank (http://www.ncbi.nlm.nih.gov/genbank). For each gene, at least three primer pairs were designed based on annealing temperature around $60^{\circ} \mathrm{C}$, size close to $20 \mathrm{bp}$ and expected fragment size around $100 \mathrm{bp}$.

\section{4 qRT-PCR Analysis}

The obtained cDNA was amplified by real-time PCR using the SYBR Green ${ }^{\circledR}$ kit. qRT-PCR analysis was performed with the 7300 Real-Time PCR System (Applied Biosystems) on 96-well plates PCR-96M2-HS-C® (Axygen) with a sealer MicroAmp ${ }^{\circledR}$ Optical Adhesive Film (Applied Biosystems).

The reactions were carried out in a final volume of $20 \mu \mathrm{L}$, consisting of $10 \mu \mathrm{L}$ of the cDNA sample (diluted 1:100) in Mili-Q water; $10 \mu \mathrm{L}$ of the constituents of the reaction composed of $2 \mu \mathrm{L} 10 \mathrm{X}$ buffer, $0.5 \mu \mathrm{L}$ dNTPs (10 $\mu \mathrm{M}$ of each nucleotide), $1.2 \mu \mathrm{L}$ of $\mathrm{MgCl}_{2}$ solution $(50 \mathrm{mM}), 2 \mu \mathrm{L}$ of SYBR Green ${ }^{\circledR}$ (Invitrogen) diluted 1:100 (prepared at the time of use from diluted 100X solution), $0.2 \mu \mathrm{L}$ of ROX Reference Dye, $0.1 \mu \mathrm{L}$ Taq

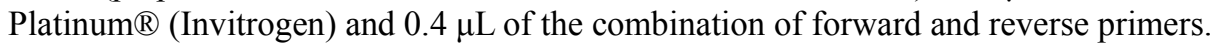

The amplification steps included an initial cycle of $95{ }^{\circ} \mathrm{C}$ for $5 \mathrm{~min}$, followed by a 40 -cycle sequence: started at $94{ }^{\circ} \mathrm{C}$ for $15 \mathrm{sec}, 60^{\circ} \mathrm{C}$ for $10 \mathrm{sec}, 72^{\circ} \mathrm{C}$ for $15 \mathrm{sec}$ and $60^{\circ} \mathrm{C}$ for $35 \mathrm{sec}$, and a final denaturation cycle of $95{ }^{\circ} \mathrm{C}$ for $15 \mathrm{sec}, 60^{\circ} \mathrm{C}$ for $60 \mathrm{sec}, 95^{\circ} \mathrm{C}$ for $15 \mathrm{sec}$ and $60^{\circ} \mathrm{C}$ for $15 \mathrm{sec}$.

\subsection{Reference Genes Stability Analysis}

Analysis of the stability of the reference genes was performed from the Ct values obtained in the qRT-PCR reaction (Wang, Ma, Huang, \& Zhang, 2015). The software RefFinder (http://fulxie.0fees.us/?ckattempt=1) was used, which is based on the algorithms geNorm, Normfinder, BestKeper and Delta Ct method. The stability coefficients (SC) were classified in each of the algorithms and, finally, a comprehensive classification of all the algorithms was determined by the program RefFinder. A lower SC value indicate greater the stability of the reference gene. The two genes with lower stability coefficients were used as reference genes in calculations of relative expression of genes related to resistance to the herbicide imazethapyr. 


\subsection{Analysis of Gene Expression}

The $\mathrm{Ct}$ values mean, the standard deviation, and the confidence interval per treatment were calculated. The relative quantification was performed by adjusting the curves by analyzing the efficiency of the PCR using the LinRegPCR software (version 12.2), which analyzes the exponential amplification curve. Values of $\mathrm{R}>0.99$, with efficiency between 1.8 and 2, and numbers of points greater than 4 were accepted (Tuomi, Voorbraak, Jones, \& Ruijter, 2010).

The relative expression was calculated using the $\Delta \mathrm{Ct}$ method (Dussault \& Pouliot, 2006), by the equation,

$$
\Delta \Delta \mathrm{Ct}=\left(\mathrm{Ct}_{\text {target }}-\mathrm{Ct}_{\text {reference }}\right)-\left(\mathrm{Ct}_{\text {calibrator }}-\mathrm{Ct}_{\text {reference }}\right)
$$

where, $\Delta \Delta \mathrm{Ct}$ is the relative expression of the gene, and the application of the result in $2^{-(\Delta \Delta \mathrm{Ct})}$ gives the variation dimension. The $\mathrm{Ct}_{\text {reference }}$ value was determined by the average of the reference genes that presented lower coefficients in the stability analysis performed in the RefFinder computational program as described above.

\subsection{Conventional PCR Analysis}

Polymerase Chain Reaction (PCR) was carried out using Thermal Cycler (Life Science Research, Bio-Rad). Each reaction was set up in $30 \mu \mathrm{l}$ volume, containing $50 \eta \mathrm{g}$ genomic DNA, $0.2 \mathrm{mM}$ dNTPs, $0.35 \mathrm{U}$ Taq DNA polimerase (Invitrogen), $0.15 \mu \mathrm{M}$ primers (forward and reverse) (Table B2), 1.3\% of DMSO 100\%, $3 \mathrm{mM}$ of $\mathrm{MgCl}_{2}$, 1X PCR buffer and water to complete the total volume. The reactions were carried out using the following cycling parameters: $94{ }^{\circ} \mathrm{C}$ for $3 \mathrm{~min}$, followed by 35 cycles of $94{ }^{\circ} \mathrm{C}$ for $30 \mathrm{sec}, 57{ }^{\circ} \mathrm{C}$ for $30 \mathrm{sec}$, $72{ }^{\circ} \mathrm{C}$ for $60 \mathrm{sec}$, and $72{ }^{\circ} \mathrm{C}$ for $5 \mathrm{~min}$. PCR products were separated by electrophoresis in $2.0 \%$ agarose gels and product size was identified using 100 bp DNA Ladder (Invitrogen). Subsequently, the PCR products were visualized using the UV transilluminator L-PIX IMAGE Release 2.6 (Loccus Biotecnologia).

The expression was evaluated in the imidazolinone-susceptible (SUSSP01) and in the -resistant (ARRGR01) populations, which does not have mutation in $A L S$ gene associated with herbicide resistance. Gene expression was evaluated in untreated leaves (T0) and leaves collected $24 \mathrm{~h}$ after treatment with imazethaphyr (T24), as described in section 2.1.

\section{Results and Discussion}

\subsection{Reference Genes Stability Analysis}

The expression levels of the reference genes in all samples (barnyardgrass population $\mathrm{x}$ herbicide treatment) evaluated by the $\mathrm{Ct}$ values from qRT-PCR reactions are presented in Figure 1. A lower Ct value indicates a greater transcription of a particular gene. The mean $\mathrm{Ct}$ values for the seven reference genes evaluated ranged from 23.35 to 32.75 . The gene with the highest number of transcripts was rubisco, followed by $18 S, 28 S, E F 1$, actin, CAP and ubiquitin.

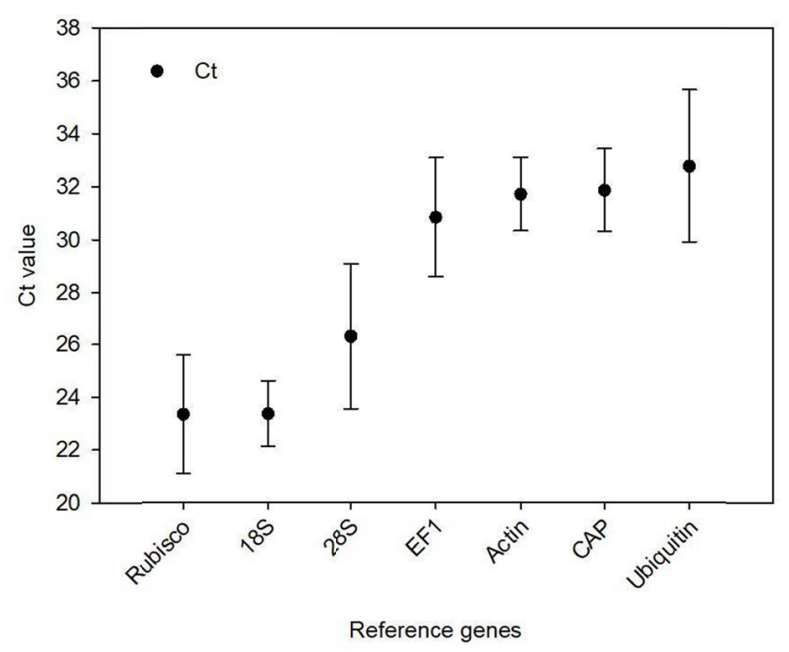

Figure 1. Ct values of reference genes in leaves of barnyardgrass (Echinochloa crus-galli) susceptible and resistant to imidazolinones evaluated before and 24 hours after spraying of imazethapyr (vertical bars indicate the standard deviation) 
Five algorithms were used to determine the stability of the reference genes. The Delta $\mathrm{Ct}$ method determines the stability of the genes according to the variation of the $\mathrm{Ct}$ value (Silver et al., 2006). In the geNorm method, the stability coefficient is called the M-value, which is calculated according to the variation of $\mathrm{Ct}$ eliminating the two less stable genes in the first round of the calculation. In this analysis, the lower the M-value the greater the stability of the reference gene (Vandesompele et al., 2002). The NormFinder method calculates the stability coefficient S and the standard deviation (SD). Reference genes are considerable stable when both S and SD values are low (Andersen, Jensen, \& Orntoft, 2004). In the BestKeeper method the variation of the Ct values and the standard deviation (SD) of each gene are used for the calculation of stability. Genes with SD $<1$ are considered stable and ordered based on the correlation between the $\mathrm{Ct}$ value and the geometric mean of the $\mathrm{Ct}$ values of all values with $\mathrm{SD}<1$ (BestKeeper index). The candidate genes with the highest correlation with the BestKeeper index are considered to be the most stable (Pfaffl, Tichopad, Prgomet, \& Neuvians, 2004). Finally, the RefFinder method uses an integrated way the other methods of analysis, classifying them comprehensively. Based on the ordering of the methods described above, the RefFinder method assigns an appropriate weight to an individual gene and calculates the geometric mean of its weights for the comprehensive classification of candidate reference genes (Xie, Xiao, Chen, Xu, \& Zhang, 2012). The stability analysis of the reference genes indicated low variations of the classification and stability among the methods used (Table 1 and Appendix A). For all the methods used, the $18 S$ and actin genes presented higher stability. Therefore, these genes were used in the relative expression calculations of the genes possibly related to the herbicide resistance.

Table 1. Stability classification of reference genes in leaves of imidazolinone-susceptible and -resistant barnyardgrass (Echinochloa crus-galli), treated and untreated with imazethapyr

\begin{tabular}{llllllll}
\hline \multirow{2}{*}{ Method } & \multicolumn{7}{c}{ Ranking order (better-good-average) } \\
\cline { 2 - 7 } & 1 & 2 & 3 & 4 & 5 & 6 & 7 \\
\hline Delta CT & $18 S$ & $A c t$ & $U b i$ & $E F 1$ & $28 S$ & $C A P$ & $R u b$ \\
BestKeeper & $18 S$ & $A c t$ & $28 S$ & $U b i$ & $E F 1$ & $C A P$ & $R u b$ \\
NormFinder & $A c t$ & $18 S$ & $U b i$ & $E F 1$ & $28 S$ & $C A P$ & $R u b$ \\
geNorm & $18 S / A c t$ & - & $U b i$ & $28 S$ & $E F 1$ & $C A P$ & $R u b$ \\
\hline RefFinder & $18 S$ & $A c t$ & $U b i$ & $28 S$ & $E F 1$ & $C A P$ & $R u b$
\end{tabular}

Note. 18S: 18S ribosomal RNA; Act: actin; Ubi: ubiquitin; 28S: $28 \mathrm{~S}$ ribosomal RNA; EF1: elongation factor 1; $C A P$ : catabolite activator protein; Rub: Rubisco.

\subsection{Expression Analysis of the ALS Gene}

The relative expression of the $A L S$ gene was not altered by the evaluated treatments (Figure 2). The expression in both resistant populations ARRGR01 and PALMS01 was similar to that observed in SUSSP01 susceptible population. Spraying of imazethapyr had no effect on the relative expression of the $A L S$ gene. This indicated that the greater expression or the greater number of copies of the $A L S$ gene is not a mechanism of resistance to imazethapyr in these populations of barnyardgrass. 


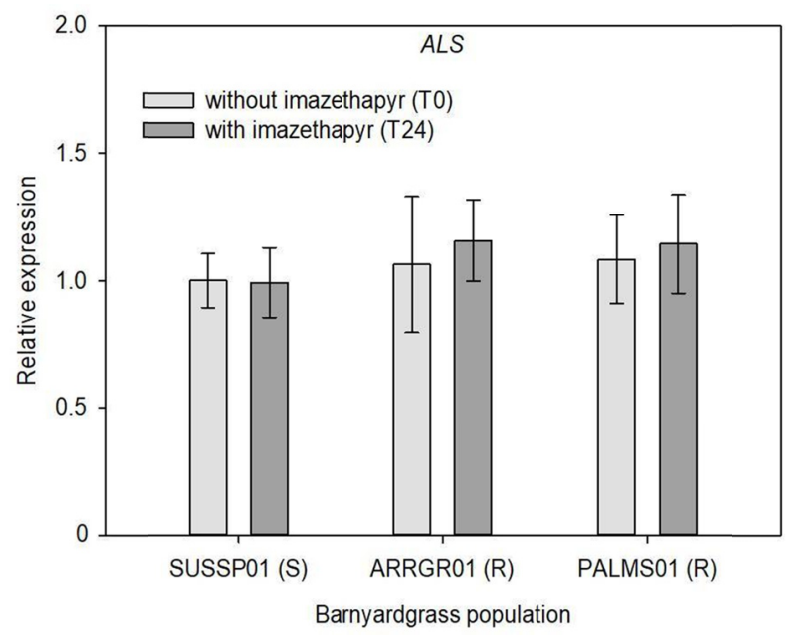

Figure 2. Relative expression of the $A L S$ gene in imidazolinone-susceptible (SUSSP01) and -resistant (ARRGR01 and PALMS01) barnyardgrass (Echinochloa crus-galli), in response to spraying of imazethapyr. T0; Untreated leaves; T24: leaves collected 24 hours after spraying of imazethapyr. Vertical bars indicate the confidence interval $(\alpha=0.05)$

\subsection{CYP and GST Genes Expression}

The expression of the genes CYP81A12, CYP81A21, CYP71C30, CYP71AK2, CYP72A254, CYP72A31, GST1 and GSTL1 was not significant different among the populations evaluated and neither due to imazethapyr spraying (data not shown). Otherwise, meanwhile the CYP81A6 and the GSTF1 presented higher expression in these conditions. The CYP81A6 gene showed higher expression in both resistant populations, especially when the plants were treated with imazethapyr (Figures 3 and 6). The relative expression of the gene CYP81A6 for resistant population ARRGR01 treated with the herbicide imazethapyr (T24) was 9.61 times greater in comparison to the untreated susceptible plants (T0). For the PALMS01 resistent population, the relative expression was 8.44 times higher when the plants were sprayed with imazethapyr (T24). The expression of the CYP81A6 gene, even in the absence of herbicide, was 4.96 fold higher in the PALMS01 population than the untreated susceptible population. For the resistant population ARRGR01, the relative expression of this gene in untreated plants was 1.67. Thus, in addition to the expression of the CYP81A6 gene in the resistant populations, the spraying of the herbicide imazethapyr induced greater expression of this gene in resistant plants.

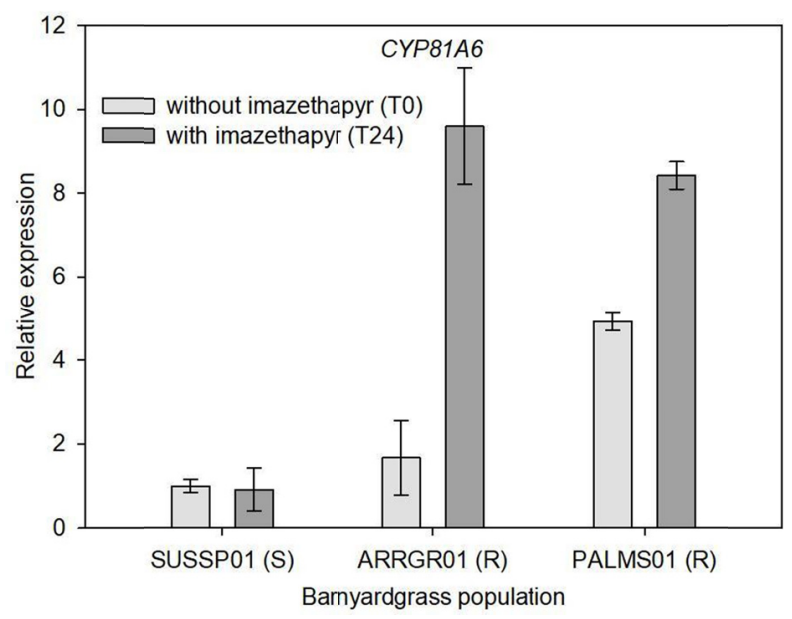

Figure 3. Relative expression of the CYP81A6 gene in imidazolinone-susceptible (SUSSP01) and -resistant (ARRGR01 and PALMS01) barnyardgrass (Echinochloa crus-galli), in response to spraying of imazethapyr. T0; Untreated leaves; T24: leaves collected 24 hours after spraying of imazethapyr. Vertical bars indicate the confidence interval $(\alpha=0.05)$ 
The relationship of the CYP81A6 gene to herbicide detoxification has already been reported in crops and weeds. Some poaceous species, such as rice $(O$. sativa $\mathrm{L}$.) and wheat (Triticum aestivum L.) are naturally tolerant to bentazon herbicides (FSII inhibitor) and to sulfonylureas (ALS inhibitors). The selectivity of these herbicides on these crops is attributed to the greater expression of the CYP81A6 gene, responsible for the phase I of the detoxification of these herbicides in the plants (Pan et al., 2006; Zhang et al., 2007). In addition, the insertion of this gene into non-poaceous species such as A. thaliana $\mathrm{L}$. and Nicotiana tabacum $\mathrm{L}$. conferred tolerance to these herbicides (C. Liu, S. Liu, F. Wang, Y. Wang, \& K. Liu, 2012). In contrast, the silencing of this gene by means of interference RNA made rice plants, previously tolerant, sensitive to the herbicide bentazon, proving the function of this gene in the process of detoxification of herbicides in plants (Liu et al., 2012). In the present study, spraying of the herbicide imazethapyr induced CYP81A6 gene expression in both resistant populations evaluated (Figure 3). Similar results were observed in rice, in which both bentazon and metsulfuron-methyl spraying caused increased CYP81A6 gene expression when compared to untreated plants (Lu et al., 2015).

The GSTF1 gene showed highest expression in the PALMS01 resistant population in leaves collected 24 hours after imazethapyr spraying (Figure 4). In plants of the ARRGR01 resistant population treated with imazethapyr (T24), the expression of this gene was 6.41 times higher than the untreated susceptible population SUSSP01 (T0) (Figures 4 and 6). However, in the absence of the herbicide (T0), the relative expression was similar to that observed in the susceptible population. In the PALMS01 population, the relative expression of the GSTF1 gene was higher in both untreated (T0) and treated (T24) plants. In untreated plants (T0), the relative expression was 10.24 times higher than the susceptible population, whereas in treated plants (T24), the expression was 12.30 times greater. It is also observed that, even in susceptible plants, there was greater expression of this gene in plants treated with imazethapyr (T24) in comparison with the untreated control plants.

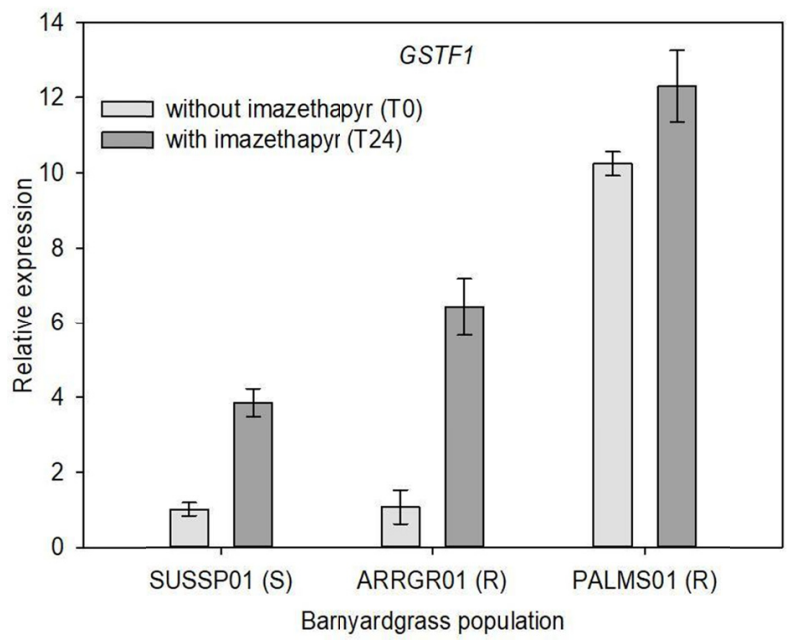

Figure 4. Relative expression of the GSTF1 gene in imidazolinone-susceptible (SUSSP01) and -resistant (ARRGR01 and PALMS01) barnyardgrass (Echinochloa crus-galli), in response to spraying of imazethapyr. T0; Untreated leaves; T24: leaves collected 24 hours after spraying of imazethapyr. Vertical bars indicate the confidence interval $(\alpha=0.05)$

The GST enzymes are involved in phase II of the herbicide metabolism in plants. In this phase occurs the conjugation of the herbicide molecule with glutathione, after being activated in phase I (Yuan, Tranel, \& Stewart Jr., 2007). However, these enzymes may also present other functions in plants, such as peroxidase activity and signaling for the production of secondary metabolites in the stress protecion (Dixon, Skipsey, \& Edwards, 2010; Powles \& Yu, 2010). In A. myosurioides, the GSTF1 gene showed low herbicide detoxifying activity, however, it was highly active as a glutathione peroxidase, catalyzing the reduction of organic hydroperoxides (Cummins et al., 1999). The presence of the same gene in A. thaliana resulted in multiple resistance to herbicides due to increased activity of peroxidase enzymes and increased accumulation of antioxidant compounds (glutathione, flavonoids and anthocyanins) (Cummins et al., 2013). Although there is little information on the formation of reactive oxygen species by ALS-inhibiting herbicides, some studies have demonstrated increase of the levels of certain antioxidant enzymes due to the presence of these herbicides (Wang et al., 2006; Wang, Zhou, \& Ren, 2009). 


\subsection{Expression Analysis of the eIF4B Gene}

In addition to the greater expression of the CYP81A6 and GSTF1 genes, the greater expression of the eIF4B translation initiator factor (Figures 5 and 6) was also observed. The relative expression of this gene in the ARRGR01 resistant population was 2.51 times higher in untreated (T0) and 6.46 fold higher in treated (T24) leaves with imazethapyr. In the PALMS01 resistant population, relative expression was 2.30 times higher in untreated (T0) and 5.96 fold higher in treated (T24) leaves with imazethapyr. In the SUSSP01 susceptible population, the relative expression of this gene was higher in leaves treated with the herbicide in comparison with the untreated plants. For all populations, spraying of imazethapyr induced expression of the $e I F 4 B$ gene. The basal expression (untreated plants) was higher in the resistant populations compared to the susceptible population.

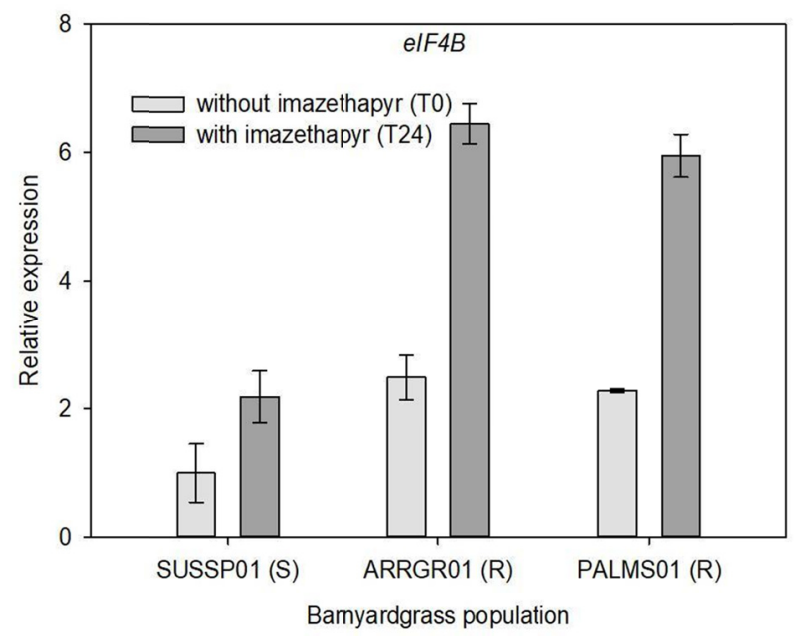

Figure 5. Relative expression of the $e I F 4 B$ gene in imidazolinone-susceptible (SUSSP01) and -resistant (ARRGR01 and PALMS01) barnyardgrass (Echinochloa crus-galli), in response to spraying of imazethapyr. T0; Untreated leaves; T24: leaves collected 24 hours after spraying of imazethapyr. Vertical bars indicate the confidence interval $(\alpha=0.05)$

The eIF4B translation initiation factor, along with other proteins that also act as translation initiators, is responsible for the process of recognition of mRNA by the ribosomes during the process of protein synthesis (Spriggs, Bushell, \& Willis, 2010). This protein presents a helicase function, responsible for the unwinding of some mRNA in the 5'-UTR region and initial codon (AUG) exposure for the initiation of translation in ribosomes (Shahbazian et al., 2010). The differential expression of this translation-initiating factor is related to the occurrence of stresses in plants, being important in post-transcriptional gene regulation in eukaryotes (Sonenberg \& Hinnebusch, 2009). In addition, the higher expression of this gene is directly related to the lower efficiency of chemotherapy in the treatment of cancer cells, and there is a high correlation between the greater expression of the $e I F 4 B$ gene and the higher production of proteins responsible for cancerous diseases (Degen, Barron, Natarajan, Widlund, \& Rheinwald, 2013). Thus, depending on the structure of the mRNA in the 5'UTR region, the higher expression of the gene $e I F 4 B$ may culminate in the higher content of detoxifying enzymes, such as P450 and GST. Therefore, the greater expression of this gene and, consequently, the greater production of this protein, can contribute to the regulation of the translation of the mRNA of enzymes P450, regulating its production and the capacity to metabolize the herbicides in resistant plants. Although this mechanism has already been reported in cases of chemotherapy for the treatment of cancer in humans (Kim et al., 2011; Degen et al., 2013), this is the first report of the possible involvement of this protein on herbicide resistance in weeds. 

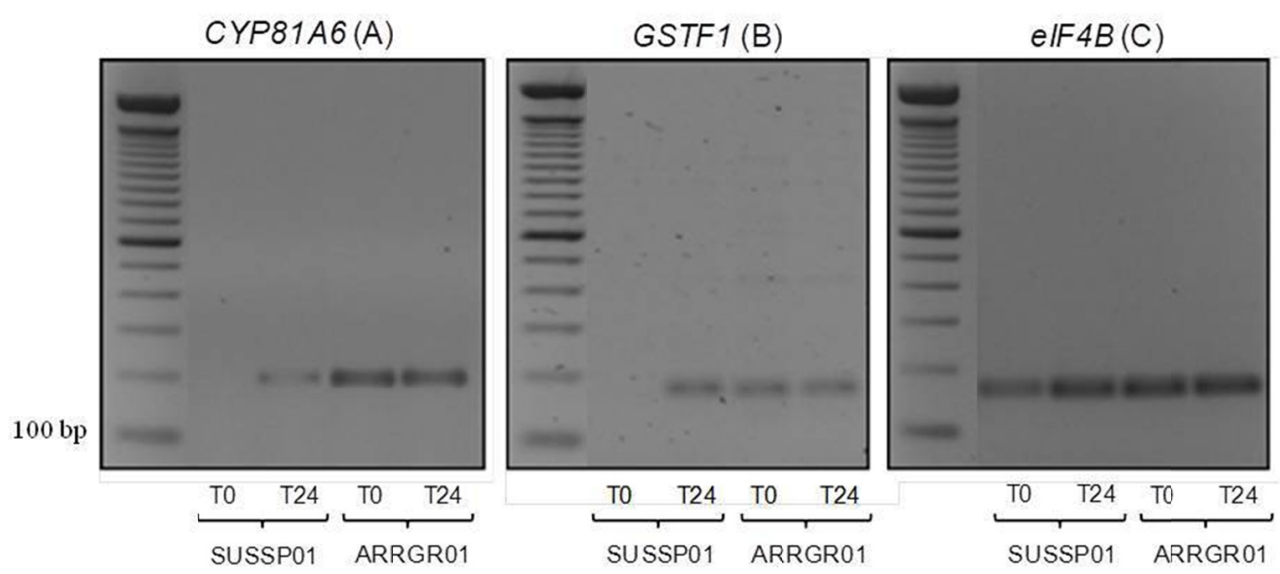

Figure 6. Expression of CYP81A6 (A), GSTF1 (B), and eIF4B (C) genes in imidazolinone-suscetible (SUSSP01) and -resistant (ARRGR01) barnyardgrass (Echinochloa crus-galli), in response to imazethapyr spray. T0: untreated leaves; T24: leaves collected 24 hours after the herbicide treatment

Stability analysis of reference genes expression demonstrated that the $18 S$ and actin were the most stable in imidazolinone-susceptible and -resistant barnyardgrass leaves, in the presence or absence of the stress caused by the herbicide imazethapyr. Expression analysis of the $A L S$ gene demonstrated that the amount of transcripts in all populations evaluated was similar among population and imazethapyr treatment. Thus, it can be stated that the greater expression of the $A L S$ gene is not the cause of the resistance of the populations evaluated in this study (Figure 2).

The CYP81A6 and GSTF1 genes showed higher relative expression in resistant populations. The CYP81A6 gene presented expression 9.61 and 8.44 times higher in the ARRGR01 and PALMS01 populations, respectively. Expression of this gene was induced by the spraying of the herbicide imazethapyr. The GSTF1 gene presented higher relative expression in the PALMS01 population, being 12.3 times higher in plants treated with imazethapyr. In addition to these genes, the greater expression of the $e I F 4 B$ translation initiator factor may be involved in the resistance of these populations to the herbicide imazethapyr. The results demonstrate that degradation enhancement by P450 and GST enzymes is involved in the resistance mechanism of these populations. This type of NTSR is particularly important because it has envolved in multiple- or cross-resistance. In these cases, the simple alteration of the chemical group or herbicide mechanism of action may not be efficacious for the management of resistant weeds. Also, the occurrence of resistance mechanisms not yet described in weeds, related to the greater activity of proteins responsible for the recognition of mRNA in the protein synthesis, require the accomplishment of more detailed studies.

The present study points out the importance of the genes CYP81A6 and GSTFlin the degradation enhancement of imazethapyr in barnyardgras. Moreover, it is reported for the first time that the translation initiator factor eIF4B was related with the herbicide resistance. These results contribute for the improving the knowledge about the genetic regulation of herbicide NTSR in weeds and could be used for developing the P450s pathway associated with the herbicida detoxification.

\section{References}

Andersen, C. L., Jensen, J. L., \& Orntoft, T. F. (2004). Normalization of real-time quantitative reverse transcription-PCR data: A model-based variance estimation approach to identify genes suited for normalization, applied to bladder and colon cancer data sets. Cancer Research, 64, 5245-5250. https://doi.org/10.1158/0008-5472.CAN-04-0496

Bajwa, A. A., Jabran, K., Shahid, M., Ali, H. H., Chauhan B. S., \& Ehsanullah. (2015). Eco-biology and management of Echinochloa crus-galli. Crop Protection, 75, 151-162. https://doi.org/10.1016/j.cropro.2015. 06.001

Beckie, H. J., \& Tardif, F. J. (2012). Herbicide cross resistance in weeds. Crop Protection, 35, 15-28. https://doi.org/10.1016/j.cropro.2011.12.018 
Busi, R., Vila-Aiub, M. M., \& Powles, S. B. (2011). Genetic control of a cytochrome P450 metabolism-based herbicide resistance mechanism in Lolium rigidum. Heredity, 106, 817-824. https://oi.org/10.1038/ hdy.2010.124

Chauhan, B. S., \& Johnson, D. E. (2011). Ecological studies on Echinochloa crus-galli and the implications for weed management in direct-seeded rice. Crop Protection, 30, 1385-1391. https://doi.org/10.1016/j.cropro. 2011.07.013

Chen, G., Xu, H., Zhang, T., Bai, C., \& Dong, L. (2018). Fenoxaprop-P-ethyl resistance conferred by cytochrome $\mathrm{P} 450 \mathrm{~s}$ and target site mutation in Alopecurus japonicus. Pest Management Science. https://doi.org/10.1002/ps.4863

Cummins, I., Wortley, D. J., Sabbadin, F., He, Z., Coxon, C. R., Straker, H. E., ... Edwards, R. (2013). Key role for a glutathione transferase in multiple-herbicide resistance in grass weeds. PNAS, 110, 5812-5817. https://doi.org/10.1073/pnas.1221179110

Dalazen, G., Pisoni, A., Rafaeli, R. S., \& Merotto Jr., A. (In press). Degratation enhancement as the mechanism of resistance to imazethapyr in barnyardgrass. Planta Daninha.

Degen, M., Barron, P., Natarajan, E., Widlund, H. R., \& Rheinwald, J. G. (2013). RSK activation of translation factor eIF4B drives abnormal increases of laminin $\gamma 2$ and MYC protein during neoplastic progression to squamous cell carcinoma. PLoS ONE, 8(10), e78979. https://doi.org/10.1371/journal.pone.0078979

Délye, C., Gardin, J. A. C., Boucansaud, K., Chauvel, B., \& Petit, C. (2011). Non-target-site-based resistance should be the centre of attention for herbicide resistance research: Alopecurus myosuroides as an illustration. Weed Research, 51, 433-437. https://doi.org/10.1111/j.1365-3180.2011.00864.x

Dixon, D. P., Lapthorn, A., \& Edwards, R. (2002). Plant glutathione transferases. Genome Biology, 3(3), 1-10.

Dixon, D. P., Skipsey, M., \& Edwards, R. (2010). Roles for glutathione transferases in plant secondary metabolism. Phytochemistry, 71, 338-350. https://doi.org/10.1016/j.phytochem.2009.12.012

Duhoux, A., \& Délye, C. (2013). Reference genes to study herbicide stress response in Lolium sp.: Up-regulation of P450 genes in plants resistant to acetolactate-synthase inhibitors. PLoS ONE, 8(5), e63576. https://doi.org/10.1371/journal.pone.0063576

Dussault, A. A., \& Pouliot, M. (2006). Rapid and simple comparison of messenger RNA levels using real-time PCR. Biological Procedures Online, 8(1), 1-10. https://doi.org/10.1251\%2Fbpo114

$\mathrm{Hu}, \mathrm{T}$. (2014). A glutathione S-transferase confers herbicide tolerance in rice. Crop Breeding and Applied Biotechnology, 14, 76-81. https://doi.org/10.1590/1984-70332014v14n2a14

Hu, T., Qv, X., Xiao, G., \& Huang, X. (2009). Enhanced tolerance to herbicide of rice plants by over-expression of a glutathione S-transferase. Molecular Breeding, 24, 409-418. https://doi.org/10.1007/s11032009-9302-y

Iwakami, S., Endo, M., Saika, H., Okuno, J., Nakamura, N., Yokoyama, N., ... Inamura, T. (2014a). Cytochrome P450 CYP81A12 and CYP81A21 are associated with resistance to two acetolactate synthase inhibitors in Echinochloa phyllopogon. Plant Physiology, 165, 618-629. https://doi.org/10.1104/pp.113.232843

Iwakami, S., Uchino, A., Kataoka, Y., Shibaike, H., Watanabe, H., \& Inamura, T. (2014b). Cytochrome P450 genes induced by bispyribac-sodium treatment in a multiple-herbicide-resistant biotype of Echinochloa phyllopogon. Pest Management Science, 70, 549-558. https://doi.org/10.1002/ps.3572

Kim, H. K., Choi, I. J., Kim, C. G., Kim, H. S., Oshima, A., Michalowski, A., \& Green, J. E. (2011). A gene expression signature of acquired chemoresistance to cisplatin and fluorouracil combination chemotherapy in gastric cancer patients. PLoS ONE, 6(2), e16694. https://doi.org/10.1371/journal.pone.0016694

Li, G., Wu, S. G., Yu, R. X., Cang, T., Chen, L. P., Zhao, X. P., ... Wu, C. X. (2013). Identification and expression pattern of a glutathione S-transferase in Echinochloa crus-galli. Weed Research, 53, $314-321$. https://doi.org/10.1111/wre.12031

Liu, C., Li, J., Gao, J., Shen, Z., Lu, B. R., \& Lin, C. (2012). A built-in mechanism to mitigate the spread of insect-resistance and herbicide-tolerance transgenes into weedy rice populations. PLoS ONE, 7(2), e31625. https://doi.org/10.1371/journal.pone.0031625 
Liu, C., Liu, S., Wang, F., Wang, Y., \& Liu, K. (2012). Expression of a rice CYP81A6 gene confers tolerance to bentazon and sulfonylurea herbicides in both Arabidopsis and tobacco. Plant Cell, Tissue Organ Culture, 109, 419-428. https://doi.org/10.1007/s11240-011-0106-5

Lu, H., Edwards, M., Wang, Q. Z., Zhao, H. J., Fu, H. W., Huang, J. Z., ... Shu, Q. Y. (2015). Expression of cytochrome P450 CYP81A6 in rice: Tissue specificity, protein subcellular localization, and response to herbicide application. Journal of Zhejiang University-Science B (Biomedicine \& Biotechnology), 16, 113-122. https://doi.org/10.1631\%2Fjzus.B1400168

Matzenbacher, F. O., Bortoly, E. D., Kalsing, A., \& Merotto Jr., A. (2015). Distribution and analysis of the mechanisms of resistance of barnyardgrass (Echinochloa crus-galli) to imidazolinone and quinclorac herbicides. Journal of Agriculture Science, 153, 1044-1058. https://doi.org/10.1017/S0021859614000768

Nandula, V. K., Wright, A. A., Van Horn, C. R., Molin, W. T., Westra, P., \& Reddy, K. N. (2015). Glyphosate Resistance in giant ragweed (Ambrosia trifida L.) from Mississippi is partly due to reduced translocation. American Journal of Plant Sciences, 6, 2104-2113. https://doi.org/10.1017/wsc.2017.56

Pan, G., Zhang, X., Liu, K., Zhang, J., Wu, X., Zhu, J., \& Tu, J. (2006). Map-based cloning of a novel rice cytochrome P450 gene CYP81A6 that confers resistance to two different classes of herbicides. Plant Molecular Biology, 61, 933-943. https://doi.org/10.1007/s11103-006-0058-z

Petit, C., Permin, F., Heydel, J. M., \& Délye, C. (2012). Validation of a set of reference genes to study response to herbicide stress in grasses. BMC Research Notes, 5(18), 1-10. https://doi.org/10.1186/1756-0500-5-18

Pfaffl, M. W., Tichopad, A., Prgomet, C., \& Neuvians, T. (2004). Determination of stable housekeeping genes, differentially regulated target genes and sample integrity: BestKeeper--Excel-based tool using pair-wise correlations. Biotechnology Letters, 26, 509-515. https://doi.org/10.1023/B:BILE.0000019559.84305.47

Powles, S. B., \& Yu, Q. (2010). Evolution in action: Plants resistant to herbicides. Annual Review of Plant Biology, 61, 317-347. https://doi.org/10.1146/annurev-arplant-042809-112119

Saika, H., Horita, J., Taguchi-Shiobara, F., Nonaka, S., Nishizawa-Yokoi, A., Iwakami, S., ... Toki, S. (2014). A novel rice cytochrome $\mathrm{P} 450$ gene, CYP72A31, confers tolerance to acetolactate synthase-inhibiting herbicides in rice and Arabidopsis. Plant Physiology, 166(3), 1232-1240.

Sammons, R. D., \& Gaines, T. A. (2014). Glyphosate resistance: state of knowledge. Pest Managemet Science, 70(9), 1367-1377. https://doi.org/10.1104/pp.113.231266

Shahbazian, D., Parsyan, A., Petroulakis, E., Topisirovic, I., Martineau, Y., Gibs, B. F., ... Sonenberg, N. (2010). Control of cell survival and proliferation by mammalian eukaryotic initiation factor 4B. Molecular and Cellular Biology, 30, 1478-1485. https://doi.org/10.1128/MCB.01218-09

Silver, N. (2006). Selection of housekeeping genes for gene expression studies in human reticulocytes using real-time PCR. BMC Molecular Biology, 7(33), 1-9. https://doi.org/10.1186\%2F1471-2199-7-33

Sonenberg, N., \& Hinnebusch, A. G. (2009). Regulation of translation initiation in eukaryotes: Mechanisms and biological targets. Cell, 136, 731-745. https://doi.org/10.1016/j.cell.2009.01.042

Spriggs, K. A., Bushell, M., \& Willis, A. E. (2010). Translational regulation of gene expression during conditions of cell stress. Molecular Cell, 40, 228-237. https://doi.org/10.1016/j.molcel.2010.09.028

Stürzenbaum, S. R., \& Kille, P. (2001). Control genes in quantitative molecular biological techniques: the variability of invariance. Comparative Biochemistry and Physiology Part B: Biochemistry and Molecular Biology, 130, 281-289. https://doi.org/10.1016/S1096-4959(01)00440-7

Thellin, O., Zorzi, W., Lakaye, B., De Borman, B., Coumans, B., Hennen, G., ... Heinen, E. (1999). Housekeeping genes as internal standards: use and limits. Journal of Biotechnology, 75, 291-295. https://doi.org/10.1016/S0168-1656(99)00163-7

Tuomi, J. M., Voorbraak, F., Jones, D. L., \& Ruijter, J. M. (2010). Bias in the Cq value observed with hydrolysis probe based quantitative PCR can be corrected with the estimated PCR efficiency value. Methods, 50, 313-322. https://doi.org/10.1016/j.ymeth.2010.02.003

Vandesompele, J., De Preter, K., Pattyn, F., Poppe, B., Van Roy, N., De Paepe, A., \& Speleman, F. (2002). Accurate normalization of real-time quantitative RT-PCR data by geometric averaging of multiple internal control genes. Genome Biology, 3(7), 1-12. https://www.ncbi.nlm.nih.gov/pmc/articles/PMC126239/ 
Wang, M., \& Zhou, Q. (2006). Effects of herbicide chlorimuron-ethyl on physiological mechanisms in wheat (Triticum aestivum). Ecotoxicology and Environmental Safety, 64, 190-197. https://doi.org/10.1016/j.ecoenv. 2005.03.032

Wang, M., Zhou, Q., \& Ren, L. (2009). Toxicological responses in wheat Triticum aestivum under joint stress of chlorimuron-ethyl and copper. Ecotoxicology and Environmental Safety, 72, 2121-2129. https://doi.org/ 10.1016/j.ecoenv.2007.09.009

Wang, X., Ma, X., Huang, L., \& Zhang, L. (2015). Identification of the valid reference genes for quantitative RT-PCR in annual ryegrass (Lolium multiflorum) under salt stress. Molecules, 20, 4833-4847. https://doi.org/10.3390/molecules20034833

Xie, F., Xiao, P., Chen, D., Xu, L., \& Zhang, B. (2012). miRDeepFinder: a miRNA analysis tool for deep sequencing of plant small RNAs. Plant Molecular Biology, 80(1), 75-84. https://doi.org/10.1007/s11103012-9885-2

Yasour, H., Osuna, M. D., Ortiz, A., Saldaín, N. E., Eckert, J. W., \& Fischer, A. J. (2009). Mechanism of resistance to penoxsulam in late watergrass [Echinochloa phyllopogon (Stapf) Koss.]. Journal of Agriculture and Food Chemistry, 57, 3653-3660. https://doi.org/10.1021/jf8039999

Yu, Q., \& Powles, S. (2014). Metabolism-based herbicides resistance and cross-resistance in crop weeds: a threat to herbicide sustainability and global crop protection. Plant Physiology, 166, 1106-1118. https://doi.org/ 10.1104/pp.114.242750

Yu, Q., Abdallah, I., Han, H., Owen, M., \& Powles, S. (2009). Distinct non-target site mechanisms endow resistance to glyphosate, ACCase and ALS-inhibiting herbicides in multiple herbicide-resistant Lolium rigidum. Planta, 230, 713-723. https://doi.org/10.1007/s00425-009-0981-8

Yuan, J. S., Tranel, P. J., \& Stewart Jr., C. N. (2007). Non-target-site herbicide resistance: a family business. Trends in Plant Science, 12, 6-13. https://doi.org/10.1016/j.tplants.2006.11.001

Zhang, L., Lu, Q., Chen, H., Pan, G., Xiao, S., Dai, Y., ... Liu, K. (2007). Identification of a cytochrome P450 hydroxylase, CYP81A6, as the candidate for the bentazon and sulfonylurea herbicide resistance gene, Bel, in rice. Molecular Breeding, 19, 59-68. https://doi.org/10.1007/s11032-006-9044-z

\section{Appendix A}

Ranking order and stability coefficients of candidate reference genes in leaves of imidazolinone-resistant and -susceptible barnyardgrass (Echinochloa crus-galli), in response to treatment with imazethapyr.

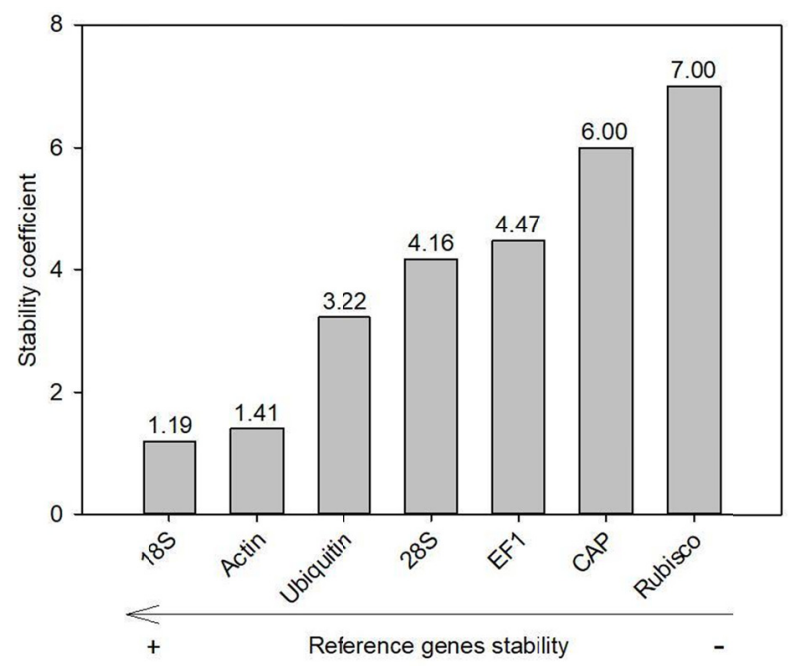

Note. A lower stability coefficient value indicates greater reference gene stability. 


\section{Appendix B}

\section{Genes and primers analyzed in the research}

Table B1. Reference genes and primers sequences used for the qRT-PCR analysis

\begin{tabular}{lll}
\hline Gene $^{\dagger}$ & Forward primer sequence & Reverse primer sequence \\
\hline$A c t$ & tttccaagggtgagtatgatgag & acacaggacacaaaagccaacta \\
$C A P$ & ctccagggaagatgctgaag & cttgaaagccccaatcaaaa \\
$E F 1$ & cactggtcacctgatctacaa & gtacttgaaggacctcttgttca \\
$R u b$ & ggagtatgaaaccaaggatactg & gttgtccatgtaccagtagaaga \\
$U b i$ & caagaagaagacgtacaccaag & gaccttgtagaactggaggag \\
$18 S$ & gtgacggagaattagggttc & tgtcaggattgggtaatttg \\
$28 S$ & ctgatcttctgtgaagggt & tgatagaactgctaatgggc \\
\hline
\end{tabular}

Note. ${ }^{\dagger}$ Act: actin; CAP: catabolite activator protein; EF1: elongation factor 1; Rub: Rubisco; Ubi: ubiquitin; $18 S$ : $18 \mathrm{~S}$ ribosomal RNA; $28 S$ : $28 \mathrm{~S}$ ribosomal RNA.

Table B2. DNA sequences of the primers used for real-time RT-PCR analysis of CYP and GST genes

\begin{tabular}{|c|c|c|c|c|}
\hline Gene & NCBI number & Forward primer sequence & Reverse primer sequence & Reference \\
\hline$C Y P 81 A 6^{\dagger}$ & DQ341412 & $\begin{array}{l}\text { gaagcccaggagtttaagca } \\
\text { gaagcccaggagtttaagca } \\
\text { gccaacctgtgggactactt }\end{array}$ & $\begin{array}{l}\text { ggcgatcatgctcttcttct } \\
\text { ttctgcagagtgagcagcac } \\
\text { tacacctccggctctgtctt }\end{array}$ & Zhang et al., 2007 \\
\hline$C Y P 81 A 6^{\S}$ & & tgtcgctactgetgaaccacccc & ttcagtcatgtcgacctccacgc & Liu et al., 2012b \\
\hline$C Y P 81 A 12^{\S}$ & AB818461 & aatcacaccgettctcctgttc & aacgttctcatcttaaatactcatacc & Iwakami et al., 2014a \\
\hline CYP81A21 & AB818463 & ccaagctgcgatcaatcattc & taatcgttcatacaaacccagtagtagt & Iwakami et al., 2014a \\
\hline СYP71C30 & AF321858 & $\begin{array}{l}\text { cttctacggcaacgacttcc } \\
\text { acgctcaccttcgagatcat } \\
\text { gctcaccttcgagatcatcc }\end{array}$ & $\begin{array}{l}\text { caaacgcctccgtcatatct } \\
\text { cggttgcagcaatacaaaga } \\
\text { cggttgcagcaatacaaaga }\end{array}$ & Fischer et al., 2001 \\
\hline$C Y P 71 A K 2^{\S}$ & AB733990 & atgacgtatgacttacccacaatg & cgatccacgacacttcaaaac & Iwakami et al., 2014b \\
\hline CYP $72 A 254^{\S}$ & AB755796 & acccaaccagccatcaggt & caaatagcgccactcaaaaac & Iwakami et al., 2014b \\
\hline$C Y P 72 A 31^{\S}$ & AB907219 & gaagaacaaacctgactacgaaggct & ctccatctctttgtatgttttccgaccaat & Saika et al., 2014 \\
\hline$G S T F 1^{\dagger}$ & HF548530 & $\begin{array}{l}\text { caagtacgtcctccgcaagt } \\
\text { acgtcctccgcaagtacaag } \\
\text { tggggatctgcttctctttg }\end{array}$ & $\begin{array}{l}\text { gggttgaagaggcattggta } \\
\text { gggttgaagaggcattggta } \\
\text { gggttgaagaggcattggta }\end{array}$ & Cummins et al., 2013 \\
\hline$G S T 1^{\S}$ & JX518596 & gccgaggaggacctgaagaac & gtgactcacagataggettaccgt & Li et al., 2013 \\
\hline$G S T L 1^{\S}$ & DQ319906 & cgcttggattatcaggaact & gctttggagattaagggtga & Hu et al., 2009 \\
\hline$e I F 4 B 1^{\dagger}$ & AB720070 & $\begin{array}{l}\text { aaggggaaagattggaggaa } \\
\text { aaggggaaagattggaggaa } \\
\text { gggaagtgattttgcaggag }\end{array}$ & $\begin{array}{l}\text { gaggcttggtcagaaccatc } \\
\text { ggettggtcagaaccatcac } \\
\text { gaggcttggtcagaaccatc }\end{array}$ & Iwakami et al., 2014 \\
\hline$A L S^{\S}$ & KJ638689 & tggcagcttcctcatgaacat & atccccaggtgttggttgttt & Matzenbacher et al., 2015 \\
\hline
\end{tabular}

Note. ${ }^{\dagger}$ Primers sequences designed from NCBI number using the software Primer3Plus. ${ }^{\S}$ Primer sequence available in the reference.

\section{Copyrights}

Copyright for this article is retained by the author (s), with first publication rights granted to the journal.

This is an open-access article distributed under the terms and conditions of the Creative Commons Attribution license (http://creativecommons.org/licenses/by/4.0/). 